\title{
A critical reappraisal of compression index equations
}

T. S. NAGARAJ and B. R. SRINIVASA MURTHY (1986). Géotechnique 36, No. 1, 27-32

Mr M. D. Howat, Hong Kong Mass Transit Railway Corporation

The correlation between voids ratio and liquid limit is perhaps far better than reported by the Authors. Table 1 shows the correlation that can be deduced from their data.

Table 1. Correlation between liquid limit and voids ratio

\begin{tabular}{c|c|c}
\hline $\begin{array}{c}\text { Consolidation } \\
\text { pressure } p: \mathrm{kPa}\end{array}$ & Voids ratio $e$ & $\begin{array}{c}\text { Correlation } \\
\text { coefficient } r\end{array}$ \\
\hline 50 & $w_{\mathrm{L}} / 50$ & 0.998 \\
500 & $w_{\mathrm{L}} / 80$ & 0.996 \\
\hline
\end{tabular}

If a small voids ratio is divided by a small liquid limit, both of which are subject to experimental errors, then of course the correlation will appear poor.

The equation that can be derived from Table 1 is given by

$$
e / w_{\mathbf{L}}=0.033-0.0075 \log p
$$

Assuming that the specific gravity of the solids is $2 \cdot 8$, then

$$
w / w_{\mathrm{L}}=e / e_{\mathrm{L}}=1.18-0.27 \log p
$$

Schofield \& Wroth (1968) suggest that the plastic limit may be more consistent than the liquid limit for estimating soil properties. However, Fig. 1 shows that, for the limited amount of data available, there may not be much to choose between the two parameters. The advantage of the liquid limit is that it can always be determined with the falling cone penetrometer, even on a fine soil which is essentially non-plastic. The Writer therefore agrees with the Authors that water content is best related to the liquid limit only and not expressed as a liquidity index.

For soils with a significant fraction coarser than the $425 \mu \mathrm{m}$ British Standard test sieve, the line separating the overconsolidated state from the cemented state (Nagaraj \& Srinivasa Murthy, 1983) can always be obtained by remoulding the soil at the end of the one-dimensional consolidation test and repeating the test. Soils with low activity can develop a sensitive structure when sedimented from a slurry (Carrier \& Beckman, 1984) so care should be taken to remould at a relatively low water content. The Writer has found that adding water until the soil ceases to ball up during mixing produces consistent, straight line consolidation curves.

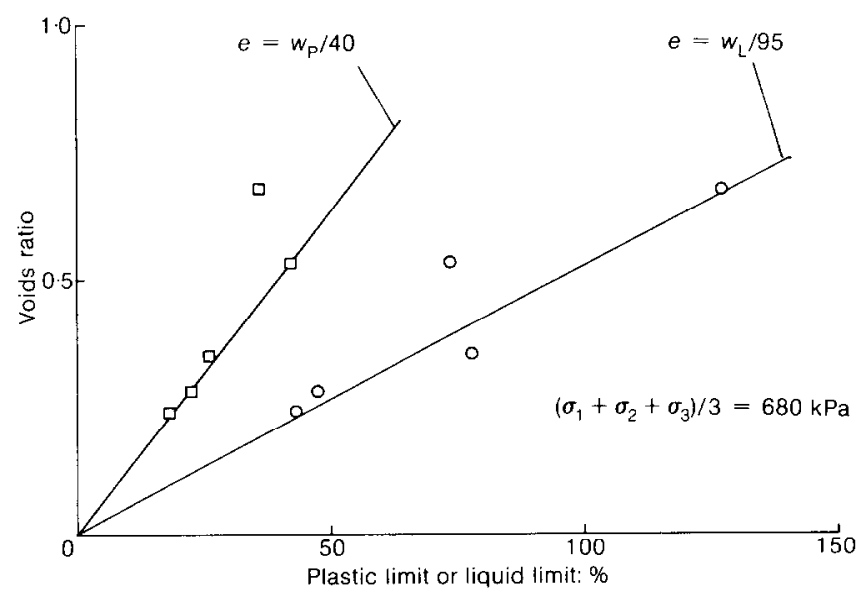

Fig. 1. Correlation between voids ratio at the critical state and Atterberg limits (after Schofield \& Wroth (1968)) 


\section{REFERENCES}

Carrier, W. D. \& Beckman, J. F. (1984). Correlations between index tests and the properties of remoulded clays. Géotechnique 34, No. 2, 211-228.

Nagaraj, T. S. \& Srinivasa Murthy, B. R. (1983). Rationalization of Skempton's compressibility equation. Géotechnique 33, No. 4, 433-443.

Schofield, A. \& Wroth, P. (1968). Critical state soil mechanics. London: McGraw-Hill.

\section{Authors' reply}

While deriving different forms of empirical compression index equations from the generalized equation it has been shown that the compression index could be a function of the liquid limit or voids ratio. Further, in the generalized equation for a given effective pressure, the correlation between the voids ratio and the liquid limit is implicd. With regard to the moulding water content, the curves used in generalizations have been remoulded at water contents close to their liquid limit. Remoulding at lower water contents may not yield a straight line at the considered initial pressure of $25 \mathrm{kPa}$. 